\title{
Mapping of Affordance and Activity as the Biophilic Design Principle of Blue Lagoon Tourism Area Yogyakarta
}

\author{
Hastuti Saptorini ${ }^{1, *}$ and Dea Viviani $^{2}$ \\ ${ }^{1}$ Lecturer at Department of Architecture, Universitas Islam Indonesia, Indonesia. \\ ${ }^{2}$ Student at Department of Architecture, Universitas Islam Indonesia, Indonesia.
}

\begin{abstract}
Bathing and playing in the river is not a new phenomenon for some people. But this experience creates a recreational spirit on the Tepusriver which is now better known as the Blue Lagoon. This area is a term for the settlement that is split a piece of the river in the dusun Ndalem Ngemplak Sleman. Its tributaries are clear and blue, surrounded by some springs with natural bamboo groves and old trees that invite local and around communities for recreation. The local community has anticipated it by responding to the communities' demands as well as the recreation area. Appear sporadically "warungs" and recreational activities follow-up though not yet grown in conceptual. This paper aims to study the map of affordance and activity of previous research findings and could be used to the biophilic design to afford the health, productivity, and wellbeing in the tourism area. The method is by synthesizing the previous research findings in 2016, some relevant urban design theories, and biophilic design principle. The conclusion is paid attention to two main principles. The first principle is maximizing the utilization of existing natural properties and the existing cultural skills into its development to nourish visitors both physically and psychologically. The second principle is the Government, and Non-Government Organizations (i.e., expertise, academics, universities, investors) support, both policy and financially, in many sectors: tourism, environment, and infrastructure.
\end{abstract}

Keywords: affordance and activity, biophilic tourism design principle

\section{Introduction}

Blue Lagoon is a popular designation for the Tepus River cutting point that develops as a "river recreation" place in a residential neighborhood in the dusun Ndalem, Ngemplak, Sleman, Daerah Istimewa Yogyakarta. The water is clear and blue, surrounded by a number of springs with natural bamboo groves and old trees that invite local communities and around to perform a number of recreative activities, both individually and communally.

Recreational activities grow in the river and banks, and in its surroundings. The author, in a previous study, found the behavior of visitors in the water nature in three places, namely river baths, sendhang wadon, and sendhang kakung. Swimming, bathing, playing theater, race on tires, etc. are activities on the river and invites other visitors. The phenomenon of the audience has not been directed and controlled because the infrastructure as a tourist area has not been prepared by default. The physical condition of nature is still pure and has not been touched by development. The undeveloped infrastructures is potential unsecure and unsafe for visitors.

Similarly, the activity conducted on the riverbanks: fishing, playing, watching theater, etc. is a phenomenal activity, both by teenagers and children. Security and safety are a threat because infrastructure has not yet constructively sustained for the public good.

This condition has not responded to Article 26 paragraph (d) in the regulation of tourism, Law no. 10 of 2009 which emphasizes the certainty of comfort, hospitality, security, and tourist safety (page 17). The basis of the regulation is also contained in the Minister of Tourism Regulation No. 14 of 2016 on Guidelines for Sustainable Tourism Destination. Clause (a) on page 14 confirms the existence of a sustainable destination strategy indicator is to address issues of health and safety issues, in addition to the general, economic, and social environment.

According to The Workers Compensation Board (WCB) of British Columbia (WCB: 2002), the "Health and Safety Program" in Yudhisthira emphasized that all activities that develop and need the planning process take into consideration 6 things as risk management. Of the six things in question, one is to emphasize "tourism planning by enacting procedures that will ensure the safety of visitors" (2012: p. 21). This is explicitly reinforced by the results of his study which found 10 parameters of tourism quality indicators in terms of safety. One of the parameters associated with the Blue

Corresponding author: hastuti.saptorini@uii.ac.id 
Lagoon phenomenon is the sixth parameter, namely the importance of infrastructure for visitor safety (page 22).

Despite the anticipatory consideration of security and safety for visitors, the Blue Lagoon needs a development concept as it is a potential tourism area. This is explicitly stated in the Minister of Tourism Regulation No. 14 of 2016 on Guidelines for Sustainable Tourism Destination. Clause (c) on page 15 confirms the existence of an indicator of a sustainable destination strategy as evidenced by evidence supporting the plural year development strategy / plan.

Theoretically, the tourism development strategy/ plan in question is based on facts and valid information of the region. This is as a matter of Godfrey K. et al (2000), that tourism strata/plans are structured through a three step process:

1. Identify opportunities and barriers based on potential and demand,

2. Establishing issue-based development objectives in the short, medium, and long term,

3. Define a stage of action designed to achieve goals in a specific and measurable timeline. Thus, the identification of facts and information, Blue Lagoon is an early stage that needs to be done to underlie the design process in its development strategy.

To date, the Blue Lagoon has not been widely identified, researched, studied, or published scientifically. Some non-scientific studies can be found, but not written and published by the Authorized Publishers. In 2016, found 2 researchers about this tourist area. First is Susi Febriani who is researching for her thesis, entitled "Participation Level of Society Tourism Activities in Blue Lagoon Tourism Village Dalem Widodomartani Ngemplak Sleman. The research aimed at 2 points, that is knowing the factors, and the level of community participation in this area, using probability random sampling technique. Researchers have interviewed 57 households of 130 household population. Data were analyzed by qualitative descriptive method. The result found 2 things. First, that the factors of community participation are influenced by age, gender, education level, occupation, and number of family members. Secondly, the level of community participation is in the medium category of $35.09 \%$.

From the research can be described that public participation is not maximized. This condition may be due to the unavailability of the whole Blue Lagoon tourism system, so that community involvement is still "sporadic and fragmentative".

The second researcher was Dea Viviani who conducted a mini research for his Scientific Writing with the title "The Behavior of Dalem Villager in the Tirta Budi Blue Lagoon Yogyakarta Tourism Object". This study aims to find the typology of dusun nDalem people's behavior towards the development of Tirta Budi Blue Lagoon tourism object. Behavior data is collected by observation and processed by way of mapping. The result is that there are routine and incidental behaviors around the river and its banks. This second study does not study affordance in terms of designing biophilic, so it has not yet identified comprehensively for environmentally-based tourist areas.

Affordance is an object/property in an environment that is likely to be utilized by both human and animal beings (Gibson, Eleanor J, et al, 1999). In the context of the Blue Lagoon, as a natural area for tourist setting, it actually has a productive biofilic environment. This 130household inhabitant still has the affordance that needs to be explored to create a biofilic activity. In principle, biophilic design is to create a healthy, productive, and wellbeing environment for its inhabitants (Abby Lerner and Mike Stopka, 2016). Biofilia refers to the existence of an instingtive bond between human beings as a species responsive to natural forms, natural analogies, and the nature of a space (Priatman, 2012: 35). This gap is a consideration of this paper. So, the objective of this paper is mapping the affordance and activities as the basic concept of biophilic design principle of Blue Lagoon tourism area Yogyakarta.

\section{Theoritical Review}

\section{Affordance}

Affordance are perceived through an invariant combination of properties, which are meaningful to a person and animals (Gibson, Eleanor J, et al: 1999), and have opportunity to creat activities in some objects of the environment (Soegaard, M: Wikipedia, https://www.interaction-design.org/literature). On the other hand, Chemero, A (2003) argue that affordance do not dissappear when there is no local animal to perceive and take advantage of them (p.193).

In terms of territory context, affordance is defined by Laurens (2004: 104) as the benefit of an area for individuals or communities to demonstrate power, defense, exclusive use, ownership, personalization, needs satisfaction, and identity through signification. This meaning is almost in line with Kytta's theory in Bobby (2011: 609). There are 3 categories in affordances, namely: perceived, utilized means 'used', and shaped means 'formed.' "As for Lindberg, P (2014) affirms, affordance is a potential activity that the environment offers to users (p. 14).

\section{Blue Lagoon Previous Research Findings}

Anonymous researcher (2014) found that Blue Lagoon has fauna properties in moderate category. There are 399 birds totally. They consist of 22 kind of birds, 20 families, 14 suku. The most numbers of Suku are Alcedinidae and Cisticilidae. From this number, there are 4 kind of birds that preserved Government related to Peraturan Pemerintah No.7/1999 Pengawetan Jenis Tumbuhan dan Satwa. Jakarta : Departemen Kehutanan. There are Cekakak Sungai, Raja Udang Meninting, Burung Madu Sriganti, and Burung Madu Kelapa. Types of high abundance birds are Bondol Jawa, and Walet Linci, while 20 other species are low in abundance. 
Viviani (2016) found that there are many behavioral tourists in Blue Lagoon. Based on research conducted on Tirta Budi Blue Lagoon tourist attraction, found two categories of tourist behavior that is routine and incidental. Both categories of behavior are carried out within the river and its banks, as well as around the river. The routine behavior of visitors conducted in the river and banks is bathing, fishing, swimming, and mutual help. They are visitors who come from inside and outside the village. The local community sells a variety fast-food, heavy or light meals at a warung stall spread across the open courtyard inside the area.

Incidental behavior that develops in rivers and banks, as well as around them, generally has a high cultural value and characterizes this area. This incidental momentum is visited not only by local communities also outside visitors, even the Sleman regent and the Governor. The behavioral typology developed in this region tends to center. The visitor's point of interest has been centered on the Tepus riverbed used as the main bath as can be seen from Figure 1. The behavior of other visitors is more widespread around a river in the Blue Lagoon area.

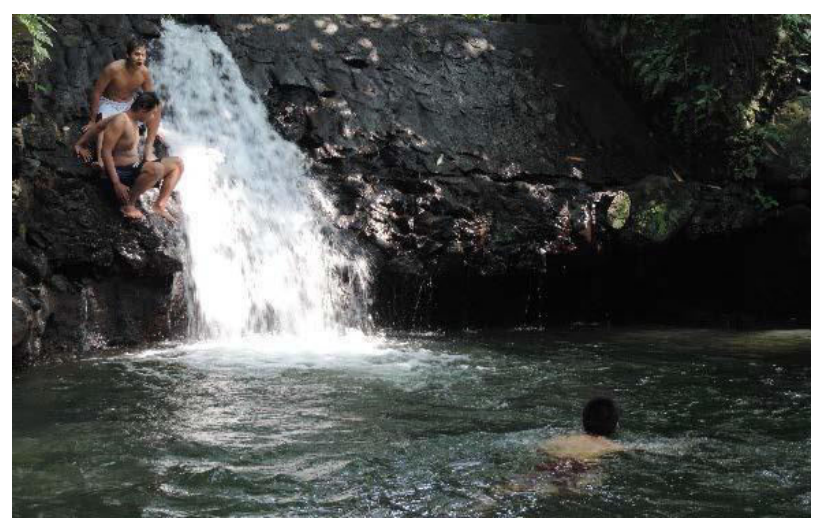

Fig. 1. Tourists' behavior in general bath as a central tourism area.

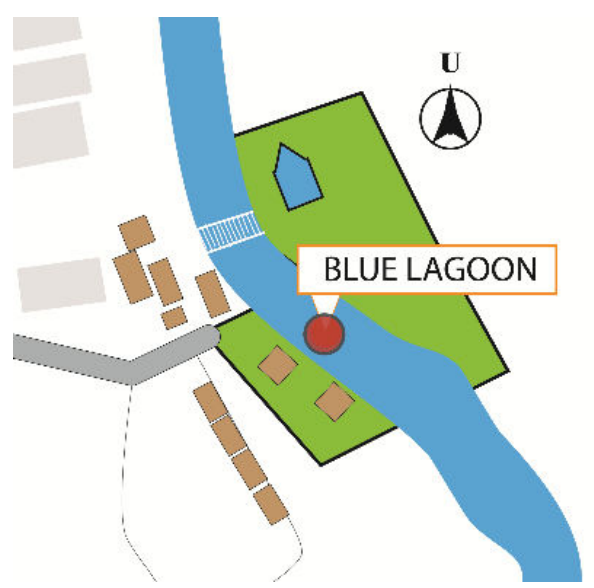

Fig. 2. The location of general bath as a central tourism area.

By collaboration with Author, the latter study was written in the context of a biology science writing contest in 2017. The title is Tirta Budi Blue Lagoon Tourism Object Development Strategy As A Potential For River Tourism and Sustainable Watershed Area. The paper concluded that Tirta Budi Blue Lagoon has a potential community that can create activities economically. This requires the design of the area in accordance with the existing potential and Government regulations on the development of river tourists area. The proposed development strategy/the finding is to emphasize the local potential of the area, both physically/environmentally and non physically/culturally (Saptorini, 2017). Here are some theories relevant to the proposals/findings.

Urban Desin Process and Tourism Policy Development Godfrey and Clarke (2000) emphazised that tourism development strategy has 3 steps. That are:

1. Identifying opportuniies and constraints (based on an evacuation of supply and demand),

2. Setting development goals and objective,

3. Define a series of action steps (Designed to achieve the goals and objectives within some specified time frame).

This theory is technically reinforced in terms of urban design by Hamid Shirvani. He examined that there are 8 eight components for considering the output of urban design (1985:p.7). These are: land use plan, mass layout, circulation, open space, pedestrian, supporting facilities, infomation, and preservation. In terms of tourism area context, Smith (1994) focussing in 5 elements and could be manifested in tourism products. Those are: physical plant, services, hospitality, freedom of choice, and involvement (p.587). This concept was figured as the circle, which the physical plant as the core.

This concept is affirmed legally through regulations issued by Tourism Minister Republic Indonesia. The regulation No.014/2016 establishes a number of criteria in the guidelines of sustainable tourism design. In principle, the scope of the guidelines for sustainable tourism destinations includes 4 verses. There are management of sustainable tourism destinations, economic utilization for local communities, cultural preservation for the community and visitors, and environmental conservation (p.3). This regulation supports the potential of Blue Lagoon in realizing as a tourism destination that prioritizes the culture and environment. The biophilic design concept is an appropriate and contextual choice with the area's condition.

\section{Biophilic Design Principle}

Biophilic design is the designing for people as a biological organism, respecting the mind-body systems as indicators of health and well-being in the context of what is locally appropriate and responsive. Good biophilic design draws from influential perspectives health conditions, socio-cultural norms and expectations, past experiences. Those are to create spaces that are inspirational, restorative, healthy, as well as integrative with the functionality of the place and the ecosystem to which it is applied. The spirit of biophilic design must nurture a love of place (p.13).

This theory is formulated by Terrapin Bright Green, LLC. 2014 in 14 Patterns of Biophilic Design. The 
principle of this strategy is still relevan to improve health, productivity, and well-beeing. The strategy is organized by 3 categories: nature in the space, natural analogues, and nature in the space as follows.

\section{Nature in the Space}

Nature in the space includes plant life, water and animals, as well as breezes, sounds, scents and other natural elements. Common examples include potted plants, flowerbeds, bird feeders, butterfly gardens, water features, fountains, aquariums, courtyard gardens and green walls or vegetated roofs. The strongest nature in the space experiences are achieved through the creation of meaningful, direct connections with these natural elements, particularly through diversity, movement and multi-sensory interactions (p.9).

\section{Natural Analogues}

Natural Analogues addresses objects, materials, colors, shapes, sequences and patterns found in nature, manifest as artwork, ornamentation, furniture, décor, and textiles in the built environment. mimicry of shells and leaves, furniture with organic shapes, and natural materials that have been processed or extensively altered. The strongest natural analogue experiences are achieved by providing information richness in an organized and sometimes evolving manner (p.10).

\section{Nature of the Space}

Nature of the Space addresses spatial configurations in nature. This includes our innate and learned desire to be able to see beyond our immediate surroundings, our fascination with the slightly dangerous or unknown; obscured views and revelatory moments; and sometimes even phobia inducing properties when they include a trusted element of safety. The strongest nature of the space experiences are achieved through the creation of deliberate and engaging spatial configurations commingled with patterns of nature in the space and natural analogues.

\section{Method}

The study method in this paper is based on a map of previous research findings, which is then linked with a number of relevant parameters from the affordance theory, the designated tourism design teory and biophilic design. The map of previous research findings is a category of visitor behavior found routinely and incidentally in rivers and banks, as well as nearby ones. The map of this finding then identified its potential properties used in biophilic design towards healthy, productive, and wellbeing areas. Diagramatically, the method of discussion of this paper as follows Fig.3.

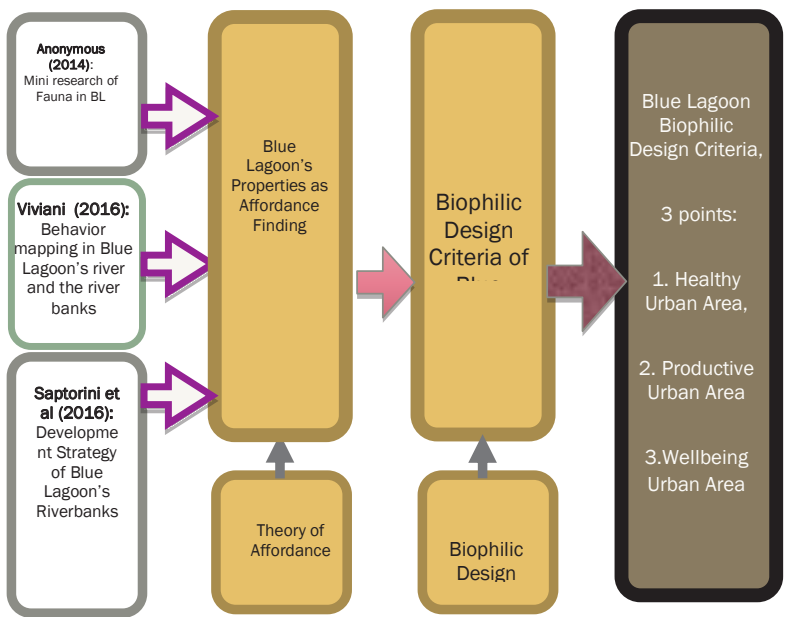

Fig. 3. Method

\section{Result And Analysis: Map Affordance and Activity to Biophilic Design Principle of Blue Lagoon Tourism Area}

This section is the result of the mapping of affordance and activity in the Blue Lagoon, and its analysis to formulate the biophilic design principle, as the purpose of this paper. By syntesizing the map of previous research findings, the theory of affordance, and the biophilic design principle, the result would be examined into 5 elements to manifesting the generic of tourism design product. These are physical plant, service, hospitality, freedom of choice, and involvement. Each point may related to the 8 urban design elements which offers the design strategic criteria to increasing the healthy, productivity, and the well-being of Blue Lagoon as the biophilic design tourism area.

\section{The Map of Previous Research Findings}

Previous Research Findings has found a map of visitor behavior that is routinely and incidentally done in rivers, banks, and its surroundings as shown in the Fig.4 Fig.11.

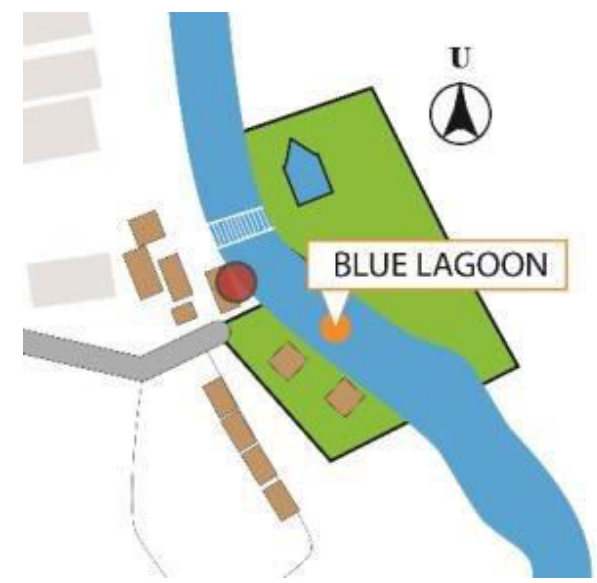

Fig. 4. Location of Routine Visitor Behavior: In The River and Banks. 


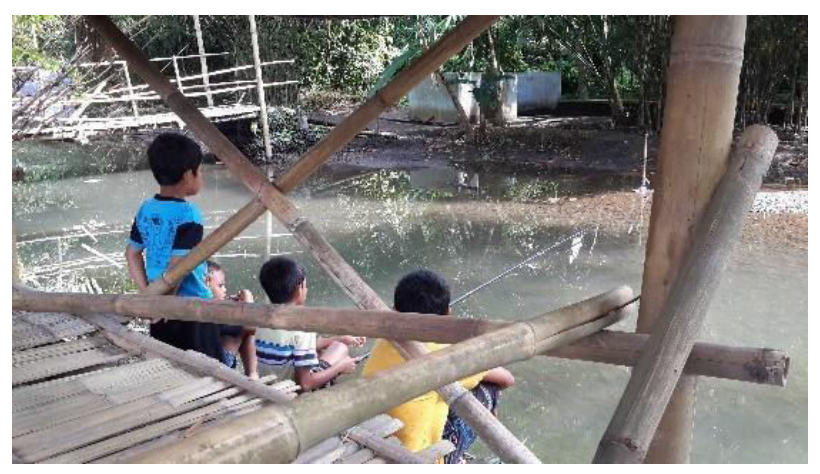

Fig. 5. Fishing, one of the routine Visitor behavior In The River and Banks.

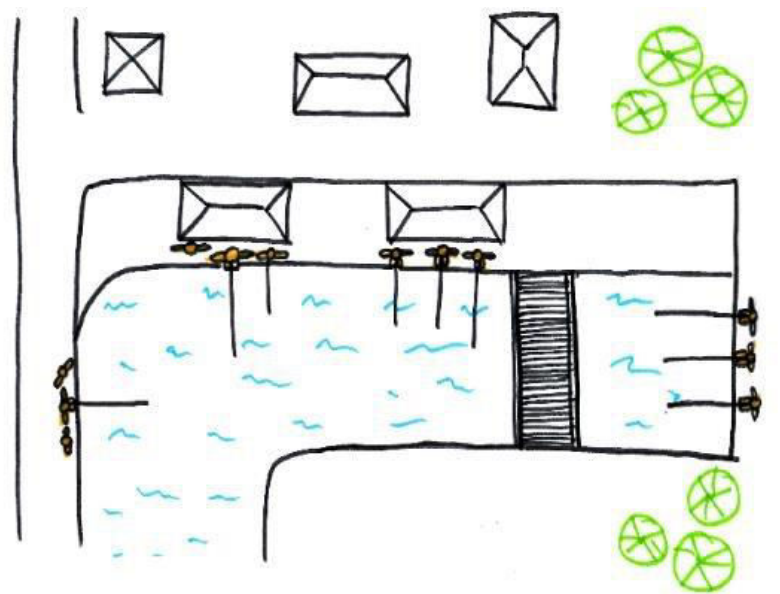

Fig. 6. Fishing, one of the routine Visitor Behavior In The River and Banks.

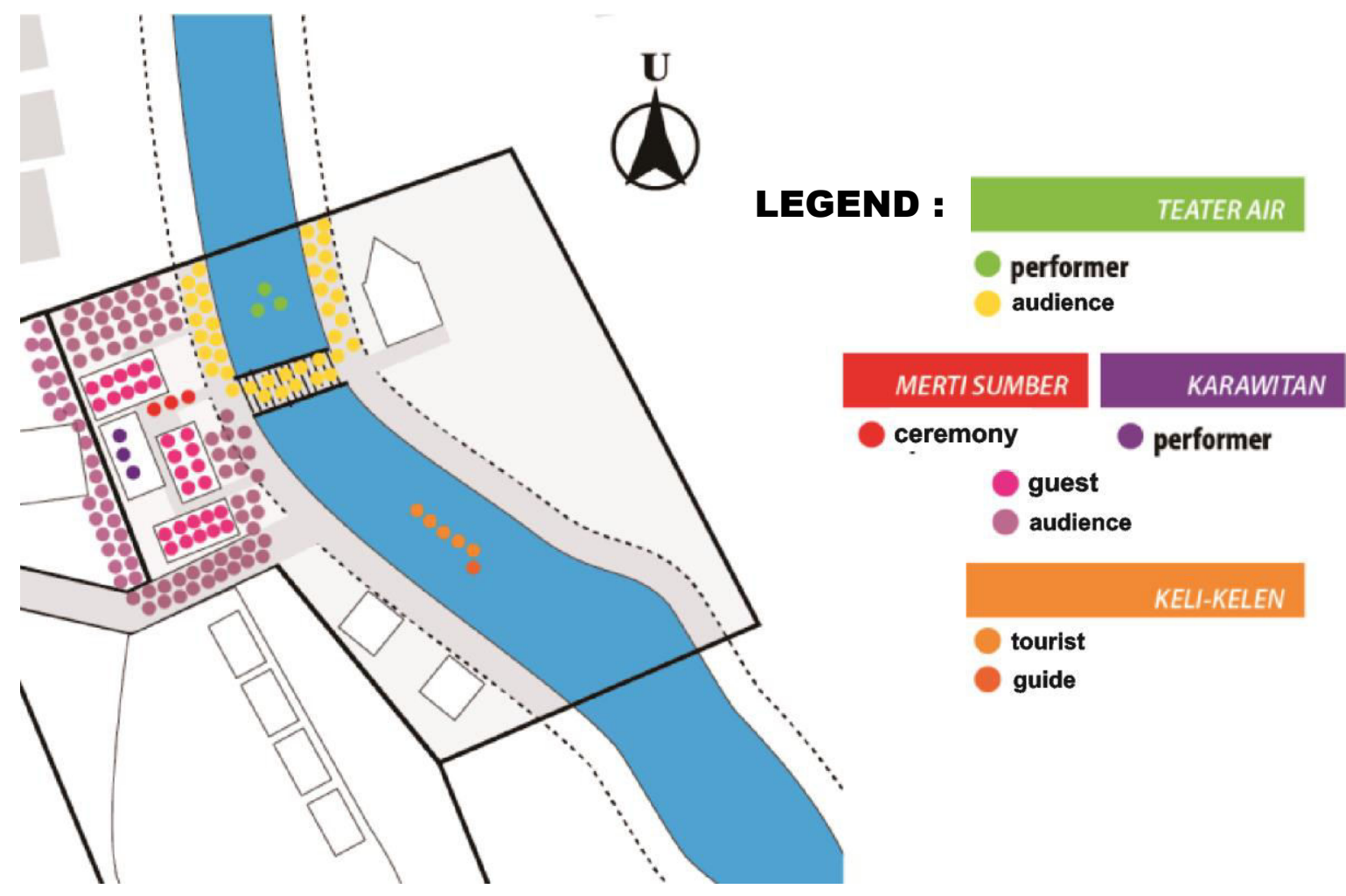

Fig. 7. Fishing, one of the routine Visitor Behavior In The River and Banks.

Fig. 8. Insidental Visitor Behavior In The River and Banks. 


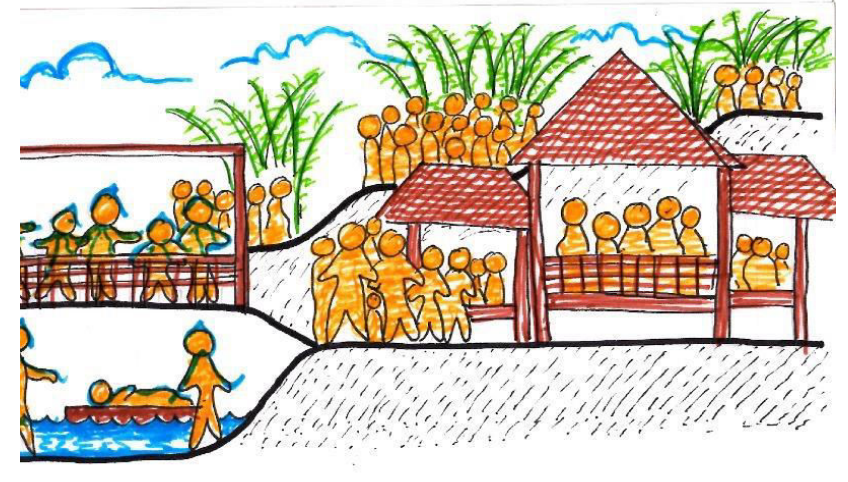

Fig. 9. Water Theatre, One of The Insidental Visitor Behavior In The River and Banks.

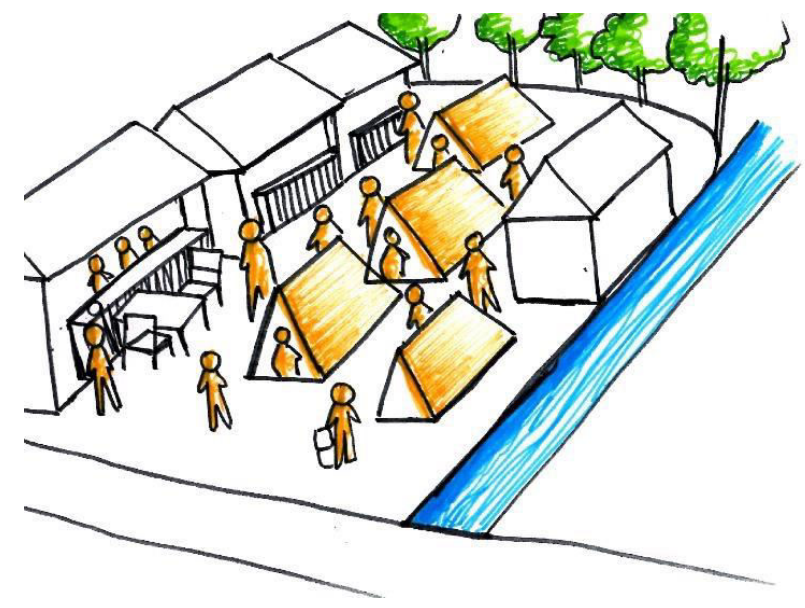

Fig. 11. Camping, One of The Insidental Visitor Behavior In The River and Its Surroundings.

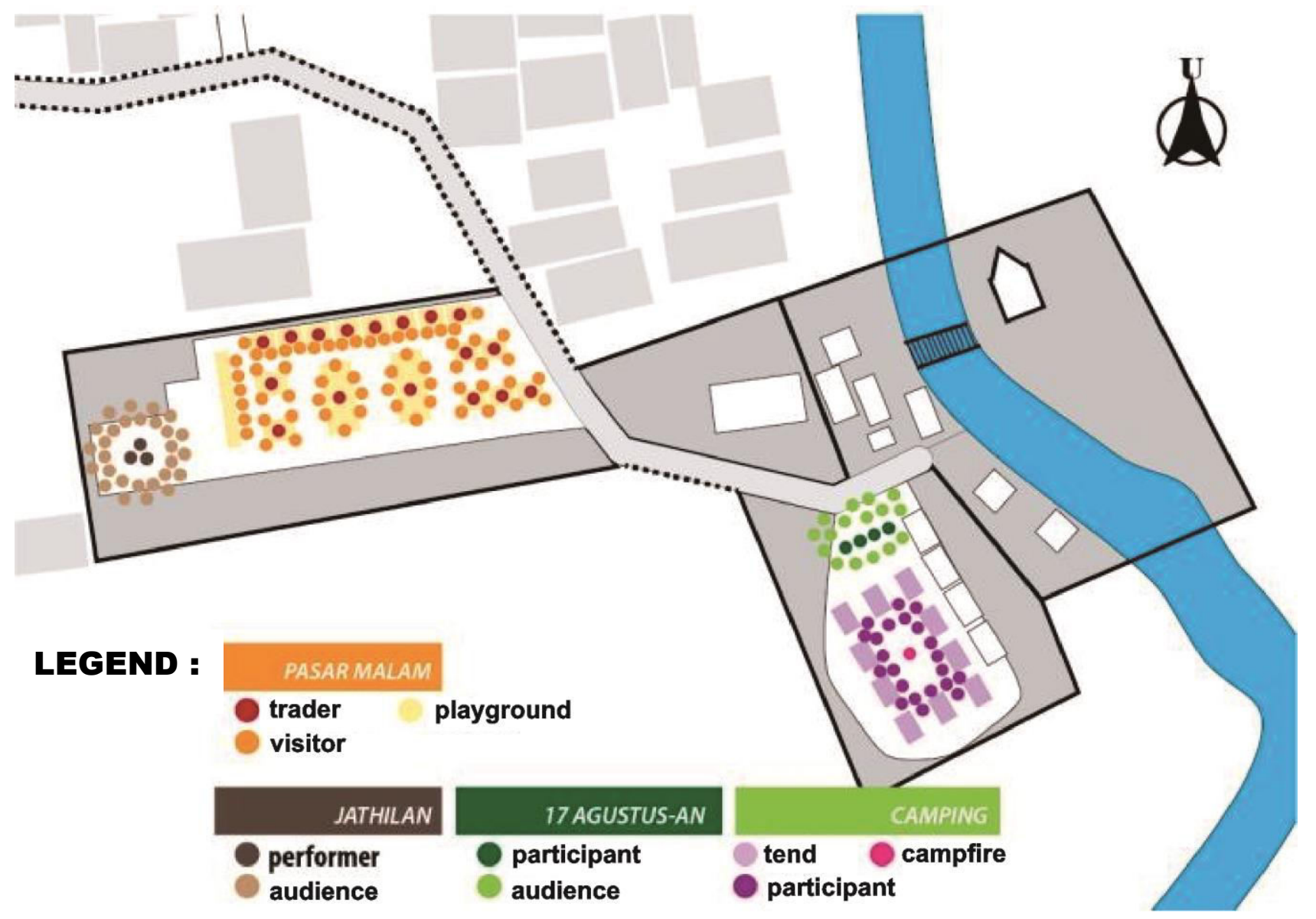

Fig. 10. Routine Visitor Behavior In The River and Its Surroundings. 


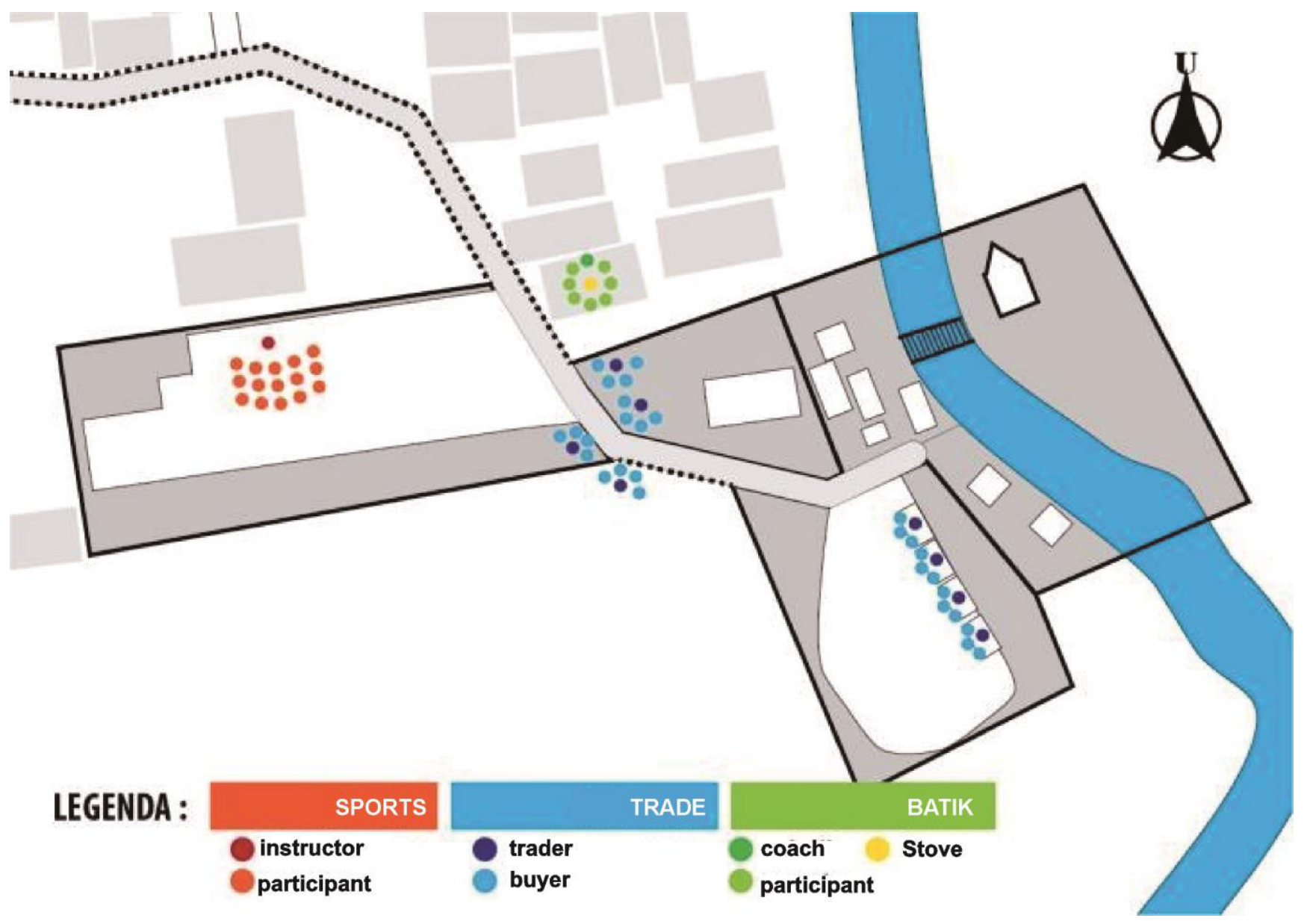

Fig. 12. Incidental Visitor Behavior In The River and Its Surroundings.

\section{Mapping of Natural Properties and The Activities}

The affordance mapping and its activities are translated as properties in the setting area that generate activity. The results are linked to the principle of biophilic design. This study is packaged into 5 elements of Smith's theory in Table 1 - Table 5 as follows.

\section{Physical plant}

The main affordance related the physical plant are the water, plant, and birds. Water is the main properties where classified in two locations: in the river and banks, and the surroundings' river. The river water is clear and blue, so tourists are interested in using pool. Swimming, swimming contest, fishing, bathing are the phenomena activities in this property.

The surrounding water are spring waters. The main spring waters are "man spring water" and "women spring water". The sub/another/child spring water are scattered throughout the area and are used to create gurgling sound sources and water plants.
Bamboo grove as we can seen in Fig.13 show that this is the dominant plant. This vegetation grew hanging over the Tepus riverbed. It is use tourists for overshadow who are swimming, swimming contest, theatre, fishing, etc. Table 1 is the mapping of main natural properties and the activities. These properties and activities are components that can be taken into consideration of the biophilic design area. As the Shirvani theory, zonification is the beginning of the design.

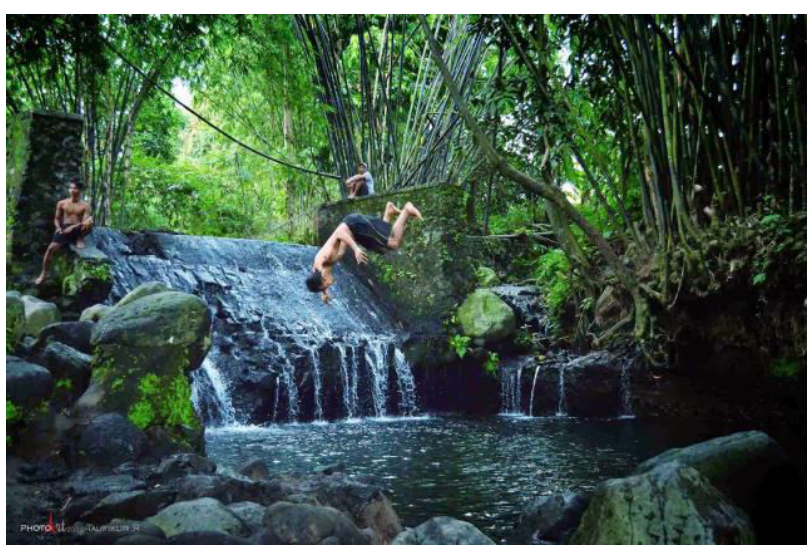

Fig. 13. Green bamboo, the dominant plant as generator tourism activities.

Source: https://www.jejakpiknik.com/blue-lagoon. 
Tabel 1. Mapping of main natural properties: water, plant, birds.

\begin{tabular}{|l|l|l|l|l|}
\hline \multicolumn{3}{|c|}{ Natural Properties } & \multicolumn{1}{c|}{ Activities } & \multicolumn{1}{|c|}{ Biophilic Design Principle } \\
\hline \multirow{2}{*}{ Water } & In the river & General baths & $\begin{array}{l}\text { Swimming, - } \\
\text { contest, bathing, } \\
\text { fishing, theatre }\end{array}$ & $\begin{array}{l}\text { Minimizing landuse change and } \\
\text { maximazing to keep up the } \\
\text { natural assets by connecting with } \\
\text { natural system }\end{array}$ \\
\cline { 2 - 4 } & Surroundings & Water springs: man, female & Bathing, washing, & \\
\hline \multirow{3}{*}{ Plants } & Dominant & Bamboo grove, bread fruit. & Perched birds & \\
\cline { 2 - 4 } Bird, goat & General & Protected PP 7/1999 & $\begin{array}{l}\text { Cekakak Sungai, Raja } \\
\text { Udang Meninting, Madu } \\
\text { Sriganti, Burung Madu } \\
\text { Kelapa }\end{array}$ & $\begin{array}{l}\text { Eating grains, } \\
\text { whistling, } \\
\text { investation }\end{array}$ \\
\hline
\end{tabular}

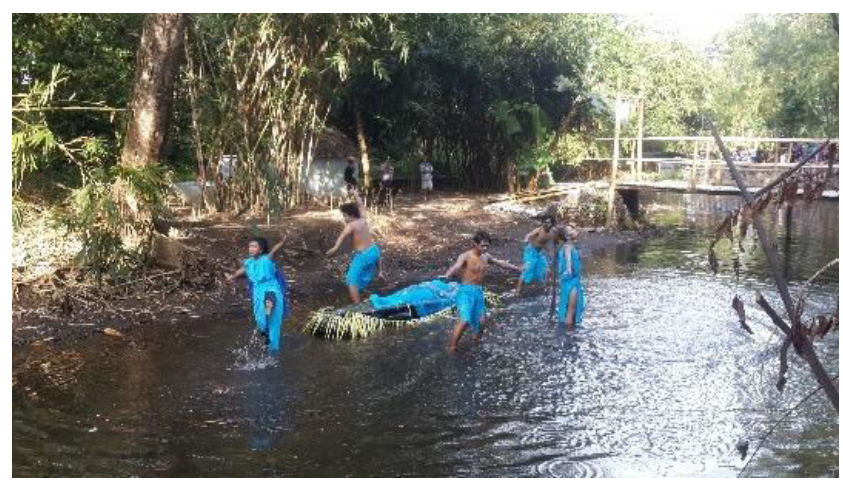

Fig. 14. Activities in the river: Swimming, bathing, fishing, theatre.

In the bamboo surroundings, there are stone hole where tourists using them for sitting while listening the frozen bamboo friction. These properties are natural resources which potential vegetation to be applied in landscape design principle for maintaining the area ecosystem chain.

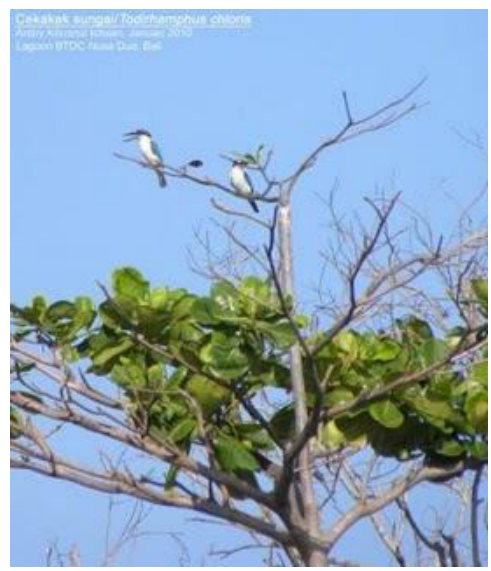

Fig. 15. Cekakak sungai bird, the protected birds. Source: https://id.wikipedia.org/wiki/cekakak_sungai.

\section{Zonification Design}

Zonification of properties and its activities is the design proposal for this area as shown in Figure 16. The natural properties are the main assets that should be keeped up and maintained as a part of biophilic design area. By minimizing land use change is the main principle of the design area.

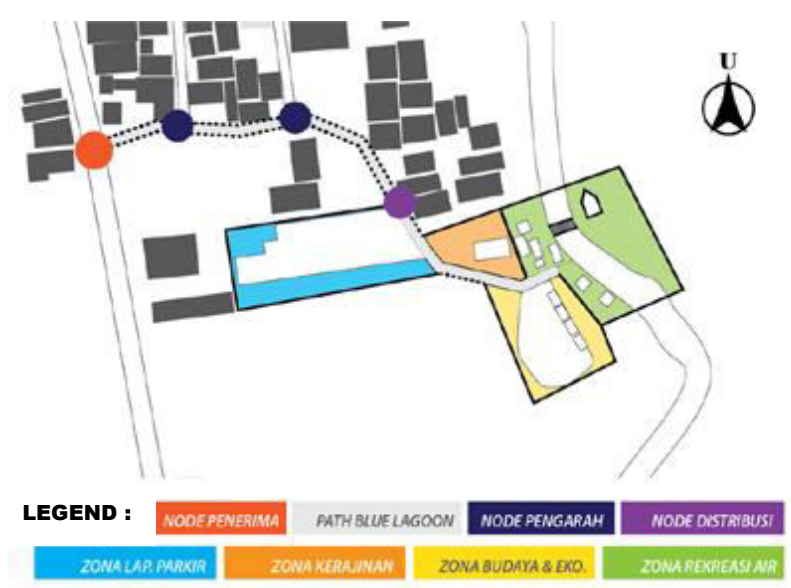

Fig. 16. Zonification Design Based On Properties and Activities.

\section{Services}

The main affordance related the services are the performance of specific task required to meet the need of tourists (Tabel 2). The tourists' need are homestay, rest area, warung makan, fit room, first aid place, prayer room, etc 
Tabel 2. Mapping of the main services properties: water, plant, birds For Tourism Services.

\begin{tabular}{|c|c|c|c|}
\hline \multicolumn{2}{|r|}{ Property } & \multirow{2}{*}{ Activities } & \multirow{2}{*}{ Biophilic Design Principle } \\
\hline Natural & Home made & & \\
\hline \multirow[t]{6}{*}{ Stone } & & sitting & \multirow{6}{*}{$\begin{array}{l}\text { Designing building layout according the } \\
\text { similar caracteristic activities. The principle } \\
\text { design is this building services could be } \\
\text { spreadly distributed in the area. }\end{array}$} \\
\hline & Bence & sitting & \\
\hline & Gubug & massage, getting a rest, & \\
\hline & Rental camera & taking picture & \\
\hline & Warung & drinking, eating, chatting & \\
\hline & Communities home & sleeping, training painting, cooking & \\
\hline
\end{tabular}

\section{Biophilic Design Principle}

Strategy to meet the tourists' needs, in principle, is setting the building layout evenly distributed. To express a natural impression, the building appearance is directed using the principle of natural element analogies. The natural asset of water, rivers, bamboo, birds, is a natural element of the Blue Lagoon that can be adopted of its form, behavior, and its color into the expression of the building.

\section{Hospitality}

The main affordance related the hospitality has been given by clear the access, walkable pedestrian, lighting, multy natural sensory: visually, auditorically, odour sensory, etc (Tabel 3).

Tabel 3. Mapping of Blue Lagoon"s Properties and Activities For Tourism Hospitality.

\section{Biophilic Design Principle}

The strategy to achieve hospitality for tourists, in principle, is to set the landscape that provides many benefits for visitors, both physically and psychologically.

Physical benefits when Blue Lagoon landscape facilitates comfort movement. This could be manifested in the form of circulation pattern arrangement in site area that flows with standard circulation. The design guidelines are sufficient road widths, constructive road surfaces, enough lighting, equipped with street furniture. The selection of shady vegetation, spread along the pedistrian pathway will overshadow tourist so thermal comfort is achieved.

Psychic benefits, when Blue Lagoon landscape provides visual comfort, auditory, and a pleasant smell for visitors. The selection of colorful shrubs grown on the knot of the pedistrian knot will attract the attention of tourists so that visual comfort is achieved. The selection of plant movement plants that produce grain seeds, will bring birds and the sound of birdsong will entertain tourists.

Filling shrubs perfume along the circulation path will produce a fragrant aroma, so visitors can be treated naturally.

\begin{tabular}{|l|l|l|l|}
\hline \multicolumn{2}{|c|}{ Property } & \multirow{2}{*}{ Activities } & \multicolumn{1}{c|}{ Biophilic Design Principle } \\
\hline & Man made & & \\
\hline & $\begin{array}{l}\text { Pintu } \\
\text { gerbang }\end{array}$ & $\begin{array}{l}\text { signing the } \\
\text { area/landmarking }\end{array}$ & Combine vegetation and manifacture elements for main gate area \\
\hline & Pedestrian & moving in the area & Construct a standard wide pedestrian for tourist walkability \\
\hline Vegetation & lighting & $\begin{array}{l}\text { Visual, atmospher } \\
\text { character } \\
\text { supporting }\end{array}$ & $\begin{array}{l}\text { Maximize natural light into the area to keep the visitor healthy and help visual } \\
\text { comfort in enjoying its natural property }\end{array}$ \\
\hline
\end{tabular}




\section{Freedom of choice}

The main affordance related the freedom of choice is in the form of tourism facility that give many optional properties for tourists (Tabel 4). For this purposes, Blue Lagoon gives optional attraction for familiy, individually, and communally. Doing in water, training some cultural skills, sensing the natural atmosphere, are the choice which be given to the tourists. Doing in water has many choices both doing bathing/swimming, and fishing in the main pool. Doing some washings (dishes and or clothes), bathing, and so on in the water springs both man and women. Training some cutural skills are choices for tourists in the form of many tranings e.g.: paintings, traditional dancing, local food cooking, and so on. Sensing the natural atmosphere has many choices both hearing the birds whistling, watterfall, visual green area, etc.

Tabel 4. Mapping of Blue Lagoon"s Properties and Activities For Tourism Freedom Of Choice.

\section{Sosio-Cultural Attraction}

Here are some design guidelines to develop a sociocultural attraction for the Blue Lagoon's community to be more productive and improve their economies.

a. Renting the camping area with a standard quality. The design strategy is to arrange with a sufficient area, the shady floor surface, protected by many shade trees, sufficient quantity bathing place and decent quality, equipped with a safe and clean public kitchen for nourish the user.

b. Providing a performance area for karawitan so that the mother community can perform periodically to entertain visitors.

c. Strengthen community skills in cooking local culinary.

d. Inviting visitors to tour the neighborhoods with local culture in the neighborhood of local architecture.

e. Having a systemic promotion management to invite regularly periodical visitors in annual merti festivals event.

\begin{tabular}{|c|c|c|c|}
\hline \multicolumn{2}{|r|}{ Property } & \multirow[t]{2}{*}{ Activities } & \multirow[t]{2}{*}{ Biophilic Design Principle } \\
\hline Natural Attraction & Sosio-Cultural Attraction & & \\
\hline \multirow[t]{5}{*}{ Water attraction } & & $\begin{array}{l}\text { Theatre, swimming, fishing, } \\
\text { kelen kelen, contests }\end{array}$ & $\begin{array}{l}\text { Maximize local material for river bank } \\
\text { construction }\end{array}$ \\
\hline & Camping area & Renting the camping facilities & \multirow{4}{*}{$\begin{array}{l}\text { Maximize community involvement in routine } \\
\text { and incedental events }\end{array}$} \\
\hline & Karawitan area & Cultural performing & \\
\hline & Village attraction & sosio living in settlement & \\
\hline & Merti sumber & Cultural festival performing & \\
\hline
\end{tabular}

\section{Biophilic Design Principle}

\section{Water Attraction}

The strategy to strengthen river cliffs used for water attractions, in principle, is to maximize the safety and security of tourists. The design guideline is maximizing the use of rocks as a construction material for river bank booster for tourist safety and security. Stone adhesive is used a strong rooted plant to knit the retaining stone.

Tourists tribune for watching the attractions allocated to a space of sufficient size and comfort visually and thermally. For that, the terracing design is proposed as the seat model. Its location is oriented under shade trees so thermal comfort environment is achieved.

\section{Involvement}

The main affordance related the involvement is the stakeholders who mandatory and potential involve (Tabel 5). They are the local community, Government, Non Government Organisation (NGO), and Investors. Their involements a re in the form of both physical and or non physical development. 
Tabel 5. Mapping of Blue Lagoon's Properties and Activities For Tourism Involvement.

\begin{tabular}{|c|c|c|c|c|}
\hline \multicolumn{3}{|c|}{ Property } & \multirow[t]{2}{*}{ Activity } & \multirow[t]{2}{*}{ Biophilic Design Principle } \\
\hline Gov & NGO & Comm & & \\
\hline $\begin{array}{l}\text { Regional } \\
\text { relationship }\end{array}$ & & & $\begin{array}{l}\text { Sleman regent is present in a number of } \\
\text { event }\end{array}$ & \multirow[t]{4}{*}{$\begin{array}{l}\text { Enhance the stakeholders' } \\
\text { development networking }\end{array}$} \\
\hline \multirow[t]{3}{*}{$\begin{array}{l}\text { Provincial } \\
\text { Relaionship }\end{array}$} & & & $\begin{array}{l}\text { The governor was present at the merti } \\
\text { source ceremony }\end{array}$ & \\
\hline & $\begin{array}{l}\text { Investor, } \\
\text { Academicions }\end{array}$ & & Supporting finance and ideas & \\
\hline & & $\begin{array}{l}\text { Gerakan } \\
\text { community: } \\
\text { fathers, mothers, } \\
\text { teenagers, children }\end{array}$ & $\begin{array}{l}\text { Organizing some culturalevents and area } \\
\text { development }\end{array}$ & \\
\hline
\end{tabular}

\section{Biophilic Design Principle}

Relationships with networks of development actors, both governmental, non-governmental, and community are the assets that Blue Lagoon already has. Therefore, communication and cooperation should be scheduled regularly and systematically. Involvement of each actor, according to the role, intensified towards the Blue Lagoon as a national tourist area, as well as international.

\section{Conclusion: Toward A Healthy, Productive, and Well-being Blue Lagoon Tourism Area}

The development of Blue Lagoon into a healthy, productive, and well-being tourist area when pay attention to the following principles.

1. Maximizing the utilization of existing natural properties is a strategic principle for the Blue Lagoon to nourish visitors both physically and psychologically.

2. The addition of plants that fit the criteria of physical and psychical comfort can be developed through the arrangement of the Blue Lagoon landscape and the building performance.

3. Capacity building of local communities is needed, especially in developing tourism development paradigm. potents should be enhancement. Cultural skills that they already have still need assistance in terms of innovation and technology.

4. Government support, both policy and financial is indispensable for the Blue Lagoon development sustainability. Not only in the sectors of tourism, environment, and infrastructure, but also in the economic and banking sectors.
5. The Non Government Organisation, such as expertist, academicions, universities, investors and also potentials stakeholders may be involved to assisst and or to advocacy the future development.

\section{References}

Febriani, Susi. 2016/09 November 2016. "Level of Public Participation in Tourism Activities In Blue Lagoon Tourism Village Dalem Widodomartani Ngemplak Sleman. "Thesis Digital. Akses 23 September 2017. URL:http//eprints.uny.ac.id/id/eprint/43435.

Chemero, Anthony. 2003. An Outline of a Theory of affordances. ECOLOGICAL PSYCHOLOGY, 15 (2), 181-195.

Gibson, Eleanor J., et al. 1999 "The MIT Encyclopedia of the Cognitive Sciences". Lokasi terbit : Nama penerbit.

Godfrey, Kerry et al. 2000. The Tourism Development Handbook. A Practical Approach To Planning and Marketing. ISBN 0304704512, 9780304704514 Cassel. Madison.

https://dokumen.tips/documents/miniriset-keanekaragamandak-kelimpahan-jenis-burung-di-obyek-wisata-bluelagoon.html

https://www.jejakpiknik.com/blue-lagoon

Laurens, Joyce Marcel. 2004. Arsitektur Perilaku, Grasindo. Jakarta.

Law of the Republic of Indonesia Number 10 Year 2009 About TOURISM

Lerner, Abby et al. 2016. The Financial Benefits of Biophilic Design in the Workplace: A Review and Summary of Current Research, MIST Environment.

Lindberg, Paivi. 2014. In search of affordances and Visual Quality. Interpreting environments of children aged under three inseven finish day-care centres. 
National Institute For Health And Welfare: Juvenes. Terveyden JA. Hyvinvoinnin Laitos. Finland.

Priatman, Jimmy. 2012. Biophilia Design Concept "as a Green Dimension on Empathic Architecture. National Seminar-Towards a Great Architecture. Jurusan Arsitektur Universitas Kristen Petra. Surabaya.

Regulation of the Minister of Tourism of the Republic of Indonesia Number 14 Year 2016 About GUIDELINES OF DESTINATION OF SUSTAINABLE TOURISMShirvani, Hamid. 1985. The Urban Design Process. New York: Van Norstrand Reinhold.

Saptorini, Hastuti et al. 2017. "Tourism Development Strategy Of Tirta Budi Blue Lagoon Yogyakarta, As A Rich Tourism Potency And Sustainable Derivative Area". Compiled to Follow the Scientific Writing Competition Biological Week 2017. Unpublished.

Smith, Stephen LJ. 1994. The Tourism Product. USA: Elsevier Science Ltd.

Soegaard, M: Wikipedia, https://www.interactiondesign.org/literature.

Terrapin Bright Green, LLC. 2014. 14 Patterns of Biophilic Design. New York: Terrapin Bright Green llc.

Yudistira, Anom IGA., et al. 2012. Rancangan Sistem Penilaian Keselamatan Pengunjung Tempat Wisata. Jurnal Teknologi. Tahun 29 Nomor 320, hal 21-22. 